\title{
Biological management of Fusarium wilt of tomato using biofortified vermicompost
}

\author{
Basco MJ, Bisen K, Keswani C, Singh HB
}

Department of Mycology and Plant Pathology, Institute of Agricultural Sciences, Banaras Hindu University, Varanasi221005, India

Basco MJ, Bisen K, Keswani C, Singh HB 2017 - Biological management of fusarium wilt of tomato using biofortified vermicompost.Mycosphere 8(3) 467-483, Doi 10.5943/mycosphere/8/3/8

\begin{abstract}
Fusarium wilt of tomato caused by Fusarium oxysporum f. sp. lycopersici is a serious problem limiting tomato production worldwide. Biological control has emerged as one of the most promising alternatives to the chemical fungicides. Biological management of Fusarium wilt of tomato using vermicompost biofortified with selected biological control agents (BCAs) i.e. Trichoderma harzianum, Pseudomonas fluorescens and Bacillus subtilis was the hypothesis of this study. In vitro test showed that all the selected microbes were antagonistic to $F$. oxysporum $\mathrm{f}$. sp. lycopersici. The levels of different antioxidants, different plant growth parameters and incidence of disease were recorded at different time intervals in designed treatments. According to the experimental results, significant variations in reduction of disease incidence, enhancement in plant growth, yield and as well as higher stimulation of antioxidants were observed in tomato plants treated with biofortified vermicompost as compared to the control. Maximum values were recorded in plants treated with $T$. harzianum fortified vermicompost.
\end{abstract}

Key words - Biocontrol agents - biological management - biofortified vermicompost - Fusarium wilt-tomato

\section{Introduction}

Tomato (Lycopersicon esculentum L.) is one of the most popular and important commercial vegetable crops grown throughout the globe. Tomatoes are excellent source of various micronutrients and antioxidants. Therefore, they are often recommended by dieticians and nutritionists for controlling cholesterol and weight reduction (Lenucci et al. 2006, Keswani 2015). Tomato plant is attacked by various diseases that significantly affect its growth and yield. Out of which Fusarium wilt is one of the most serious diseases affecting its yield. This disease is caused by Fusarium oxysporum f. sp. lycopersici (Sacc.) and the yield loss due to this disease is 25.14$47.94 \%$ in Uttar Pradesh (Enepsa and Dwivedi 2014). Fusarium spp. are well established soil borne pathogens in all soil type throughout the world. Fusarium spp. are saprophytes and are able to grow on soil organic matter for a prolonged period.

Like many other plant diseases, control of fusarium wilt is achieved by application ofsystemic fungicides and use resistant cultivars (Cook 1993, Agrios 2005). However, the widespread use of chemicals fungicides has been a subject of public concern and security due to 
their potentially harmful effects on environment and human health and their undesirable effect on non-target organisms (Heydari et al. 2007, Keswani el al. 2014, Bisen et al. 2015).

Various studies have reported the suppression of plant pathogens by thermophilic organic compost including Rhizoctonia, Phytopthora, Plasmidiophora brassicae, Gaeumannomyces graminis and Fusarium (e.g. Pitt et al. 1998, Kannangowa et al. 2000, Cotxarrera et al. 2002). Traditionally produced thermophilic organic composts support the growth of selected microbes while vermicomposts harbor vast microbial diversity and activity. Presence of a wide range of antagonistic bacteria in vermicompost ensures the effective biocontrol of soilborne phytopathogenic fungi (Scheuerell et al. 2005, Singh et al. 2008).

In addition to the individual use of biological control agents or compost, biofortification of compost with biocontrol agents (BCAs) have been proposed to enhance the process of colonization of BCAs in the composts (Sahni et al. 2008, Sarma et al. 2010). It has been reported that several composts and/ biofortified composts used as soil amendments reduced the density of pathogen propagules and protect plants from soil borne pathogens (Huang 1991, Khalil \& El-Mghrabia 2010, Mokhtar \& Mougy 2008). Tiunov \& Scheu (2004) reported that the use of vermicasts as carriers for plant growth promoting bacteria resulted in an increased survival of bacteria for at least 12 months. Vermicasts as a carrier material supported the survival of more than $1 \times 10^{7} \mathrm{~g}^{-1}$ viable cells of Azotobacter chroococum, Bacillus megaterium and Rhizobium leguminosarum up to $10^{\text {th }}$ months (Sekar and Karmegam 2010). It has also been reported that vermicompost/compost application plays an important role in increasing the levels of antioxidants (ROS-scavenging systems in case of pathogen attack) in hosts in comparison to the application of inorganic fertilizers (Suneetha 2011).

\section{Materials \&Methods}

\section{Plant materials}

Seeds of tomato (Lycopersicon esculentum L.), variety Herra were obtained from ICARIndian Institute of Vegetable Research, Varanasi, India. Seeds were surface sterilized with $0.1 \%$ $\mathrm{HgCl}_{2}$ for $30 \mathrm{sec}$, washed thrice with sterile distilled water and sown as per experimental design.

\section{Isolation, purification and maintenance of pathogen}

Infected vascular tissues from stem and root regions of tomato showing wilt symptoms were collected separately from agricultural field of Banaras Hindu University, Varanasi, India. Tissue bits were surface sterilized with $3 \%$ sodium hypochlorite for 3 minutes and subsequently washed thrice with sterile distilled water. Then, they were placed on potato dextrose agar (PDA) medium separately and incubated in BOD incubator at $25 \pm 3^{\circ} \mathrm{C}$ for 5 days. The culture was identified based on morphological characters like micro-conidia and macro-conidia (Subramanyam 1970, Booth 1971, Suresh et al. 2011). The pathogen was purified separately by transferring the tip of the mycelia into fresh PDA plates and maintained on PDA slants which were stored at $4{ }^{\circ} \mathrm{C}$ as stock cultures for further studies.

\section{Pathogenicity test of isolated fungi}

Pathogenicity test of the isolate was conducted according to Jasnic et al. (2005). Pathogenicity of the isolated pathogen was tested by sowing of tomato plants in artificially infected soil mixture made of sterilized soil and fungi suspension. Fungal suspension was prepared by pouring $50 \mathrm{ml}$ autoclaved water in Petri plate containing 10 days old Fusarium culture, stirring the culture with sterilized glass rod. Conidial concentration was measured by heamocytometer. It was set to $1 \times 10^{6}$ conidia $\mathrm{ml}^{-1}$. Control plants were sown in soil with sterile distilled water. Plants were incubation at $22-25^{\circ} \mathrm{C}$ for 14 days.

\section{Source of BCAs used and viability test}

The biological control agents used in this study viz. Trichoderma harzianum (ATCC No. PTA3701), Pseudomonas fluorescens (GenBank accession JN128891) and Bacillus subtilis (GenBank 
accession No. JN099686) were obtained from the culture repository of Plant Health Clinic Laboratory of the Department of Mycology and Plant Pathology, Institute of Agricultural Sciences, Banaras Hindu University, Varanasi, India.

\section{In vitro efficacy of BCAs against pathogen}

The antagonistic ability of selected BCAs against the pathogen was studied invitro following a dual culture assay as described by Verma et al. (2007). $9 \mathrm{~mm}$ disc (plug) of 15 days old cultures of $F$. oxysporum f. sp. lycopersici were cut with a sharp cork borer from the growing edge of the culture plate. The cut block was placed on PDA medium $1 \mathrm{~cm}$ away from the edge of the plate. 9 mm disc of biocontrol agent namely $T$. harzianum isolate was placed at opposite end of the Petri plate. PDA plates inoculated with the pathogen alone served as the control and incubated at $25 \pm 2^{\circ} \mathrm{C}$.

Similarly, the in vitro antagonistic ability of the bacterial isolates was studied using a dual culture assay described by Azadeh et al. (2010). A 9mm plug of the $F$. oxysporum f. sp. lycopersici was placed at the centre of a Petri plate containing PDA, then the test bacterial isolate was streaked $3 \mathrm{~cm}$ away from the fungal plug at both the sides towards edge of the plate by a loop loaded with $48 \mathrm{~h}$ old bacterial culture. The plates were incubated at $28 \pm 2{ }^{\circ} \mathrm{C}$ for 7 days and the inhibition zone was measured from the edge of mycelium to the bacterial streaks, when the control plates showed full growth (Shanmugam et al. 2011). \% inhibition over control was calculated as per the following formulae given by Whipps (1997):

$$
\mathrm{PI}=\frac{\mathrm{C}-\mathrm{T}}{\mathrm{C}} \times 100
$$

Where, $\mathrm{PI}=\%$ inhibition over control $\mathrm{C}=$ Growth of test pathogen with absence of antagonist $(\mathrm{mm}) . \mathrm{T}=$ Growth of test pathogen with antagonist $(\mathrm{mm})$

\section{Microbial fortification of vermicompost}

The three BCAs viz. T. harzianum, P. fluorescens and B. subtilis used in this study were chosen because of their compatibility and ascertained ability to reduce the soilborne diseases in various crops (Singh et al. 2013). All these selected BCAs were used to fortify the vermicompost individually. 1 litre of two days old bacterial cultures grown in NB with CFU count approximately $2 \times 10^{8}$ was thoroughly mixed with $25 \mathrm{~kg}$ of freshly prepared vermicompost in separate trays while 1 liter of five days old T. harzianum culture grown in PDB with CFU count approximately $4 \times 10^{7}$ was used to fortify other separate vermicompost tray $(25 \mathrm{~kg}$ each). Trays were kept under shade and covered with dark polythene sheet for 10 days for acclimatization of BCAs.

\section{Survival of the BCAs in fortified vermicompost}

To determine the adaptability (survival) of the BCAs in vermicompost, population density of different biocontrol agents was followed in the fortified vermicompost, ten days after fortification by serial dilution plates. $1 \mathrm{gm}$ of fortified vermicompost was diluted in $10 \mathrm{ml}$ sterilized water and population densities were measured on a PDA and NA media for fungi and bacteria, respectively. Microbial counts were expressed as CFU gm ${ }^{-1}$ dry wt.

\section{Pot experiments}

Plastic pots of $15 \mathrm{~cm} \times 10 \mathrm{~cm}$ were used to conduct the plant growth promotion and antagonistic potentials of fortified vermicompost against $F$. oxysporumf. sp. lycopersici. Soil was autoclaved for $30 \mathrm{~min}$ at $15 \mathrm{psi}$ for three consecutive days. Pots were filled with soil mixture containing sterile soil and microbially fortified vermicompost in the ratio of $1: 1(\mathrm{w} / \mathrm{w})\left(1.5 \mathrm{~kg}\right.$ pot $^{-}$ $\left.{ }^{1}\right)$. In the first three treatments, vermicompost was fortified individually with $T$. harzianum, $B$. 
subtilis, and P. fluorescens cultures as described above. Fourth treatment contained only vermicompost (positive control), while the fifth treatment contained only soil (Negative control).

\section{Pathogen inoculation}

The spore suspension of inoculum was prepared by pouring $20 \mathrm{ml}$ of sterile distilled water in each culture plate of 5-7 days old fungal mycelium and then gently scraped using spore harvester. The concentration of conidia was adjusted to $2-3 \times 10^{7}$ conidia $\mathrm{ml}^{-1}$ using haemocytometer. $5 \mathrm{ml}$ of prepared spore suspension was used to inoculate each seedling in all five treatments using soil drenching method as described by Patil et al. (2011). In the soil drenching method, $5 \mathrm{ml}$ of fungal suspension (i.e. water containing conidia of the pathogen) was inoculated to each of the seedlings by drenching the soil around the root zone with the helpof pipette. Before inoculation, the roots were slightly severed (wounded) by inserting a needle, $1 \mathrm{~cm}$ away from the stem. Root severing was done to ensure pathogen penetration through roots. Observations were recorded on wilt symptoms for up to 5 weeks.

Basic growth parameters namely number of leaves per plant, shoots length, root length, fresh weight and dry weight were measured at four different intervals (i.e. 15 days, 45 days, 60 days and 90 days) after transplanting. Number of fruits per plant and weight of fruits per plant were also recorded.

\section{Biochemical analysis}

Biochemical analysis for determination of different antioxidants and ROS $\left(\mathrm{H}_{2} \mathrm{O}_{2}\right)$ in the leaves of tomato plants at different time intervals after pathogen inoculation was performed according to the method of Singh et al. (2013). The enzymatic assays namely phenylalanine ammonia-lyase (PAL), peroxidase (PO), polyphenol oxidase (PPO), superoxide dismutase (SOD) and total phenol content (TPC) was performed after 0, 24, 48, 72 and $96 \mathrm{~h}$ pathogen inoculation as described by Jain et al. (2011).

\section{Determination of disease incidence}

The disease incidence was recorded on a scale of $0-4$ referring to the degree of wilt as reported by Song et al. (2004) where scale zero refers to healthy plant without any wilt symptoms. On the other hand scale four refers to complete wilted plants. The scale 1,2 and 3 refers to different degrees of wilt which indicates the scale of disease severity. The scale 1-plant showed yellowing of leaves and wilting ranging from 1-20\%; scale 2- plant showed yellowing leaves and wilting ranging from 21-40 \%; scale 3- plant showed yellowing leaves and wilting ranging from 41-60\%. Scale 4- is when all leaves become yellow as an indication of complete infection. Disease incidence is a parameter which includes disease percentage and disease severity according to Song et al. (2004) as given below:

Disease incidence $(\%)=\frac{\sum \text { scale } \times \text { number of plants infected }}{\text { highest scale } \times \text { total number of plants }}$

\section{Statistical analysis}

The data collected was subjected to statistical analysis by analysis of variance method (ANOVA), suitable to completely randomized design (CRD) for laboratory and pot experiment with help of Genstat package. Microsoft Excel (version 2007) was used to do the data entry and normalization as well as in the preparation of figures. Significant differences among treatments were based on the F-test in ANOVA and treatment means were compared using least significant difference (LSD) at $\mathrm{P} \leq 0.05$. Different letters have been used to indicate significant differences among treatments of results taken at same time interval. The standard error (SE) of the mean in vertical bar charts was computed using Sigma Plot 11 (http://www.sigmaplot.com). The results and discussion are based on the arithmetic mean of the trials during the period of research. 


\section{Results}

\section{Isolation and characterization of the pathogen}

The isolated pathogen was identified by the mycelial colony and morphology of the conidia. The mycelia of Fusarium oxysporum f. sp. lycopersici (Sacc.) W.C. Snyder and H.N. Hans are slightly white to pink when observed from PDA plate and often with a pink color on the lower side.Micro conidia formed singly, oval to reniform and without any septation. The size of micro conidia ranged from 7.54-16.20 $\times 2.5-6-4.0 \mu \mathrm{m}$. The macro conidia were elliptical with gradually pointed ends and usually 3 -septed. The size of macro conidia ranged from 28.0-44.0× 3.0-5.0 $\mu \mathrm{m}$.

\section{In vitro efficacy of $\mathrm{BCAs}$ against the pathogen}

The above described BCAs were evaluated for antagonistic activities against $F$. oxysporum f. sp. lycopersici after 4 days in dual culture assay. Table 1 shows that the bioagents significantly reduced the radial growth of $F$. oxysporum f. sp. lycopersici. $T$. harzianum showed more antagonistic activity than $B$. subtilis and P. fluorescens against the radial growth of $F$. oxysporum $\mathrm{f}$. sp. lycopersici.

Table1 Effect of bioagents on the growth of $F$. oxysporum f. sp. lycopersici

\begin{tabular}{lcc}
\hline Microbial strain & Radial growth $(\mathbf{c m})$ & Inhibition Percentage (\%) \\
\hline B. subtilis & $1 \pm 0.1^{\mathrm{b}}$ & $88.86 \pm 1.66^{\mathrm{c}}$ \\
P. fluorescens & $1.45 \pm 0.02^{\mathrm{c}}$ & $83.88 \pm 0.2^{\mathrm{b}}$ \\
T. harzianum & $0.46 \pm 0.15^{\mathrm{a}}$ & $95.18 \pm 1.69^{\mathrm{d}}$ \\
Control & $9.0 \pm 0^{\mathrm{d}}$ & $0.0 \pm 0^{\mathrm{a}}$ \\
\hline
\end{tabular}

\section{Survival of BCAs in vermicompost}

Total microbial population present in vermicompost was determined before fortification with selected microbes. The isolation was done using serial dilution method with suitable media NA and PDA for bacteria and fungi, respectively. Large number of fungal and bacterial species including Aspergillus, Fusarium, Mucor, Penicillium and Trichoderma were present in the vermicompost. However, we estimated only three BCAs of our interest, i.e. P. fluorescens, Bacillus sp. and Trichoderma sp. The colonies formed with BCAs were expressed as CFU g-1. The isolation showed that among the bacteria grown on NA plate, the population of Bacillus was approximately $6 \times 106$ (CFU g-1). No colonies could have been identified as P. fluorescens. The population of Trichoderma sp. was found at the level of $8 \times 104$ (CFU g-1). Re-isolation of selected BCAs after ten days of biofortification of vermicompost revealed that the population of $B$. subtilis, $P$. fluorescens and T. harzianum were 6.9×108, 4.4×107and 5.6×106 CFU g-1, respectively.

Table 2 Microbial dynamics after fortification of vermicompost.

\begin{tabular}{lcc}
\hline BCAs & $\mathbf{0}$ day after fortification $\left(\mathbf{C F U g} \mathbf{g}^{-1}\right)$ & $\mathbf{1 0}$ days after fortification $\left(\mathbf{C F U} \mathbf{g}^{\mathbf{- 1}}\right)$ \\
\hline B. subtilis & $2 \times 10^{7} \pm 0.52^{\mathrm{a}}$ & $6.9 \times 10^{8} \pm 0.61^{\mathrm{b}}$ \\
P. fluorescens & $1.8 \times 10^{8} \pm 0.74^{\mathrm{b}}$ & $4.4 \times 10^{7} \pm 0.81^{\mathrm{a}}$ \\
Trichodermasp. & $3.3 \times 10^{6} \pm 0.08^{\mathrm{a}}$ & $5.6 \times 10^{6} \pm 0.06^{\mathrm{a}}$ \\
\hline
\end{tabular}

The dynamics of microbial population observed in biofortified vermicompost 10 days after fortification indicated that there was a high adaptability of the selected BCAs. 


\section{Plant growth promotion assay}

Plant growth parameters were recorded at 15, 45 and 60 days interval from the date of seedling transplanting. The average number of branches/plant and yield parameters were also recorded after 90 days.

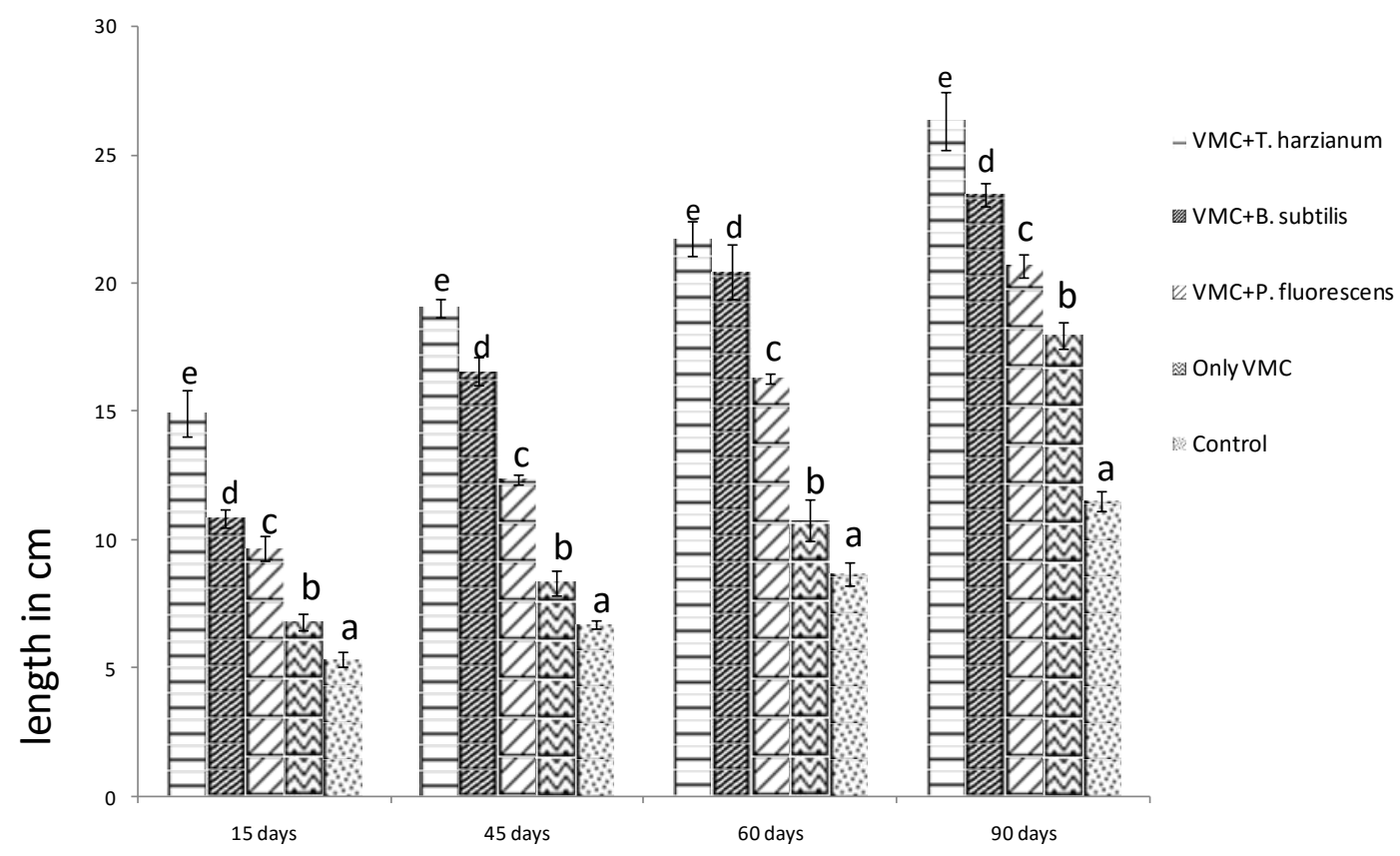

Fig. 1 -Effect of different treatment on root length of tomato plant

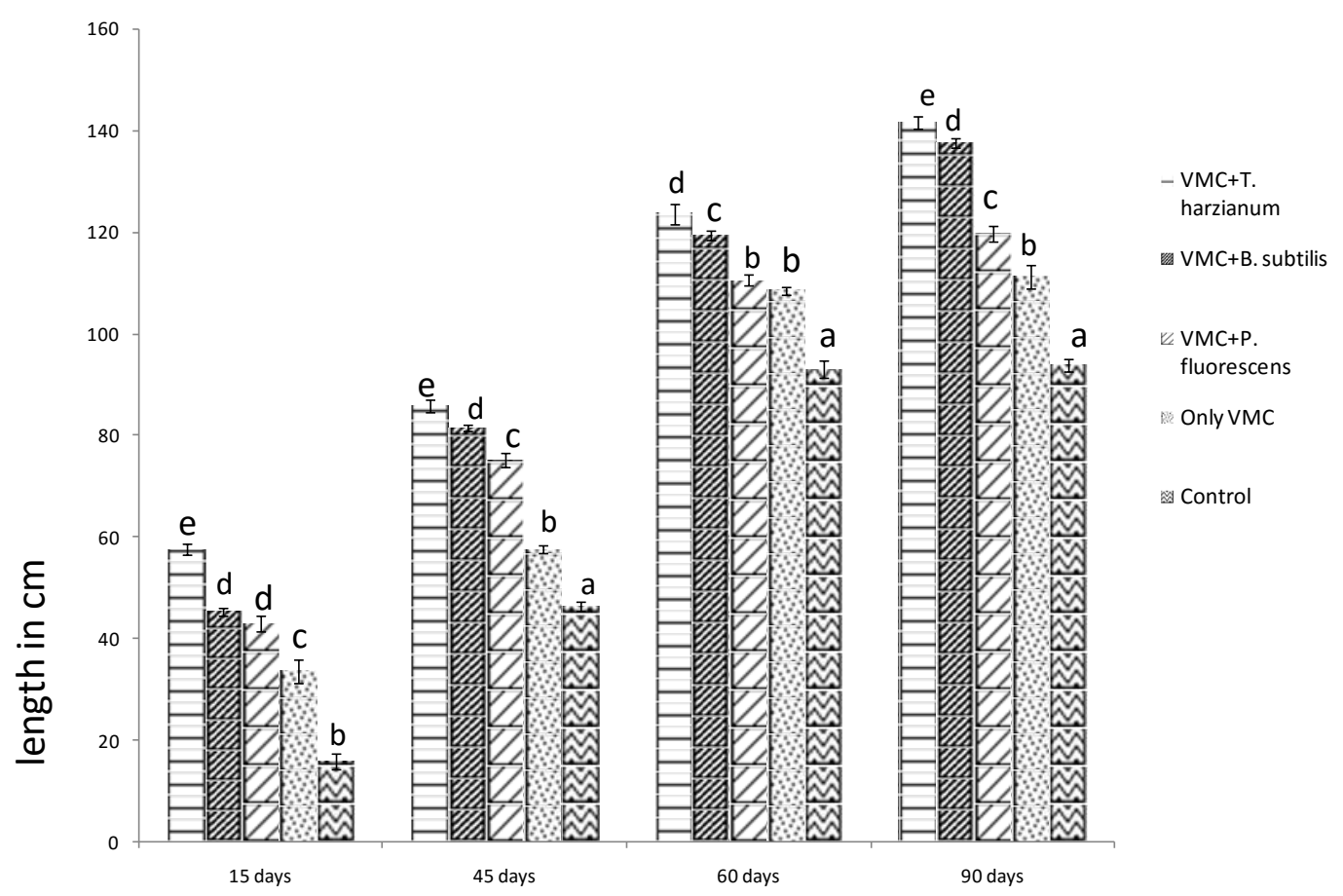

intervals

Fig. 2 - Effect of different treatment on shoot length of tomato plant 


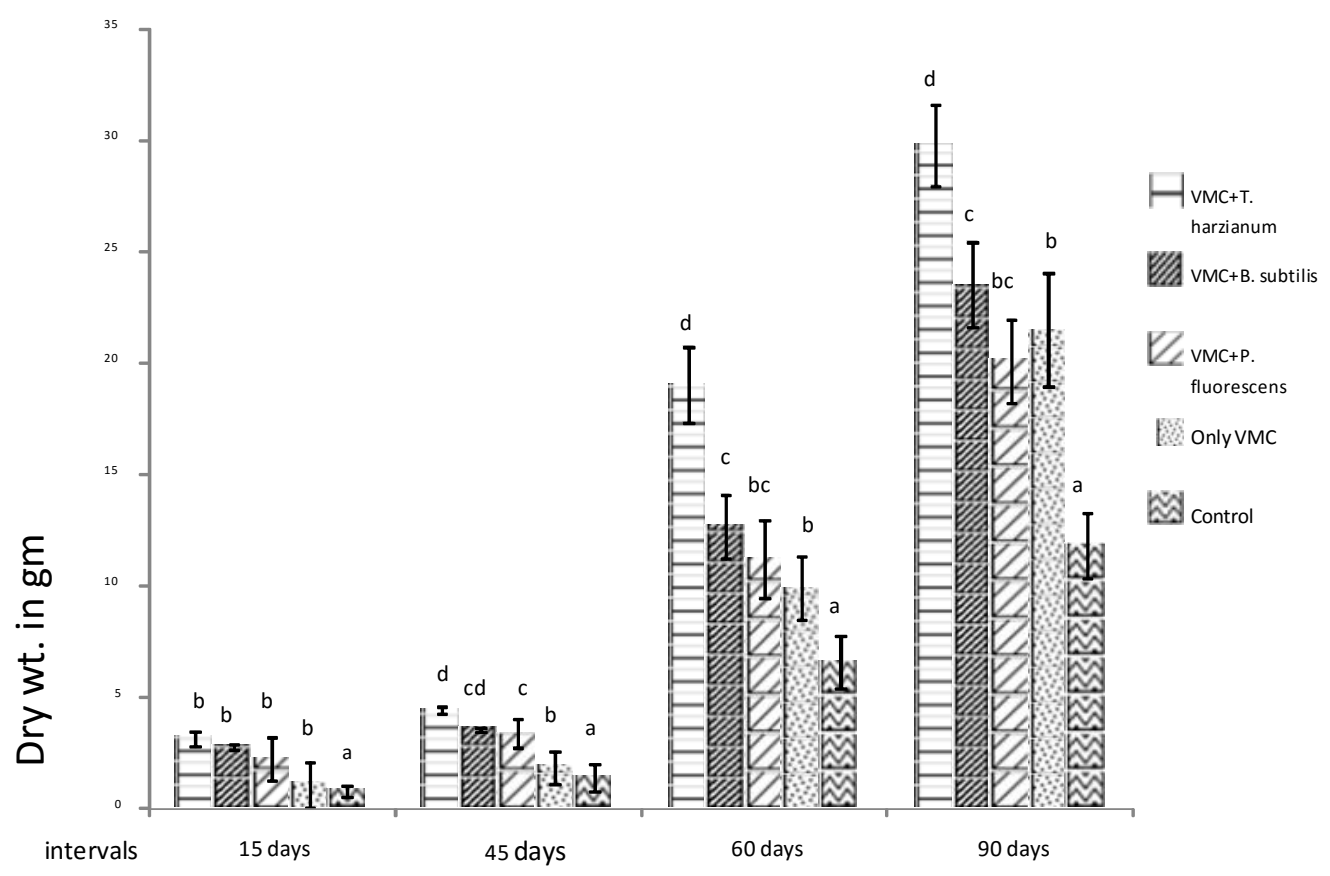

Fig. 3 - Effect of different treatment on dry weight of tomato plants

The influence of different microbes used for fortification of vermicompost on the growth characters was clearly observed after 15 days of transplanting. All treated plants showed significant improvement in root length and shoot length in comparison to the control. Highly significant changes were observed in root length. Maximum root length $(14.95 \mathrm{~cm})$, shoot length $(57.5 \mathrm{~cm})$ and dry weight $(3.15 \mathrm{~g})$ were observed in case of $T$. harzianum fortified vermicompost fortification (Figs. 1, 2 and 3). The treated plants showed maximum shoot length. Maximum root lengths, $(19.03 \mathrm{~cm})$, shoot length $(85.74 \mathrm{~cm})$ and dry weight $(4.42 \mathrm{~g})$ was observed in case of the plants treated with vermicompost $+T$. harzianum. In the first two observations in 15 and 45 days after transplanting were very fluctuating. Thereby, at this stage it was not easy to screen the treatment which could be considered as the superior treatments. For this reason, the data was recorded after 60 and 90 days as wellwhich provided credible basis for drawing conclusion of this experiment. In fact, in all cases the plants treated with either vermicompost or with bioagents showed highly significant differences. Maximum values were observed in the plants treated with T. harzianum fortified vermicompost.

From the aforementioned data, it is clear that the promising results concerning the microbial fortified vermicompost on growth promotion was evident in only two weeks after transplanting. $T$. harzianum fortified vermicompost was the first treatment to respond to the stimulation of vegetative growth.

\section{Biochemical Analysis}

The level of PAL activity was significantly different among the treatments $(\mathrm{P} \leq 0.05)$. It varied from $236.059 \pm 2.4$.to $2182.681 \pm 0 \mu \mathrm{M}$ TCA g ${ }^{-1} \mathrm{FW}$. The peaks in most treatments were evaluated during 48 and 72 hours, respectively and then declined gradually. PAL activities in all treatments were significantly higher than that in the control (Figure 4). The degree of PAL induction in the leaves were ranked in the following order: $\mathrm{VMC}+T$. harzianum> $\mathrm{VMC}+B$. subtilis $>\mathrm{VMC}+P$. fluorescens $>$ Vermicompost only> soil only. 


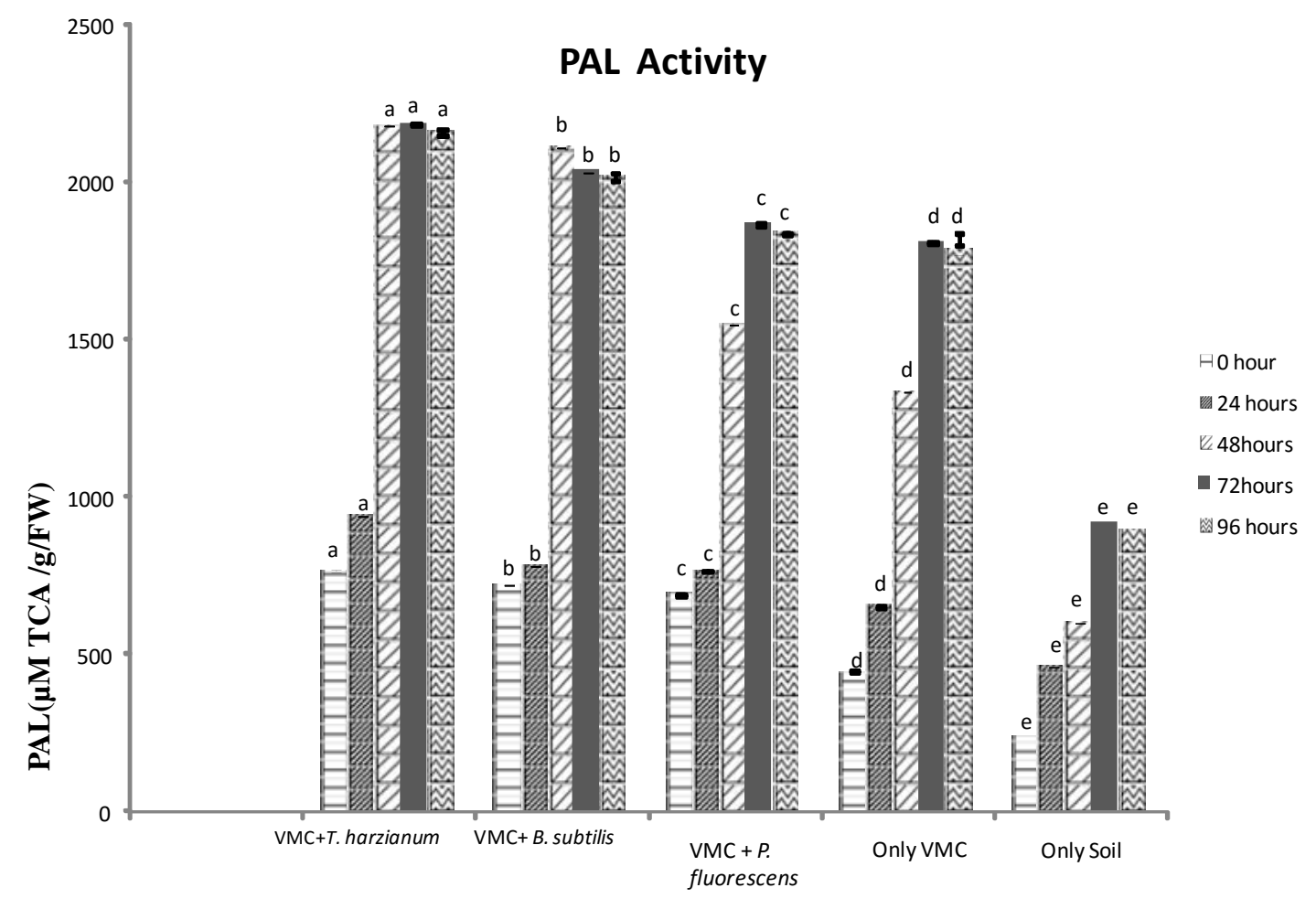

Fig.4 -Effect of microbial fortified vermicompost on PAL activity. Results were expressed as means of triplicates and vertical bars indicate standard deviation of the means. Different letters indicate significant differences among treatments of results taken at same time interval according to Duncan's multiple range test at $\mathrm{P} \leq 0.05$ )

\section{PO Activity}

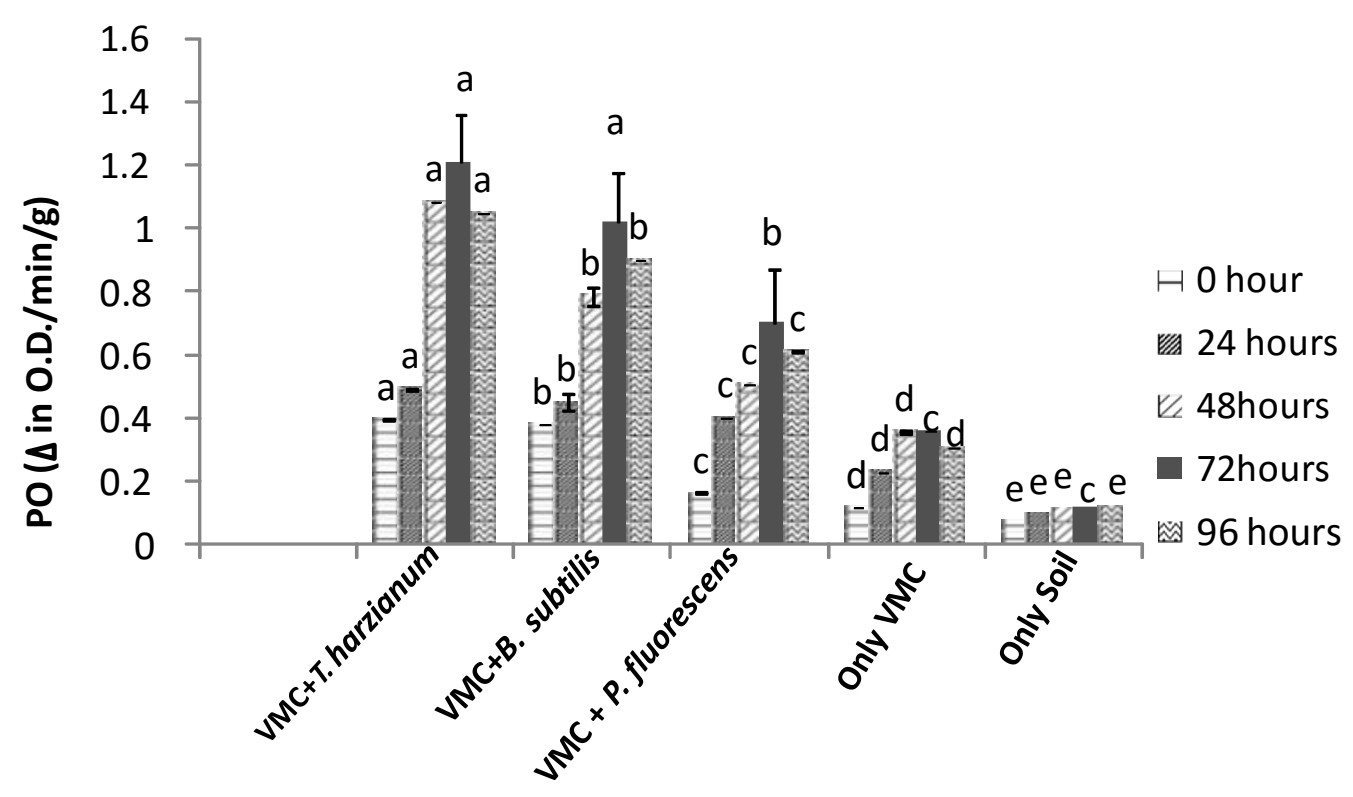

Fig.5 -Effect of microbial fortified vermicompost on PO activity. Results were expressed as means of three replicates and vertical bars indicate standard deviation of the means. Different letters 
indicate significant differences among treatments of results taken at same time interval according to Duncan's multiple range test at $\mathrm{P} \leq 0.05$ )

The rapid induction of $\mathrm{PO}$ activity in the leaves was observed during $72 \mathrm{hrs}$ after pathogen inoculation. The variation of PO was from $0.073 \pm 0.0$ to $1.21 \pm 0.057$ O.D. $\mathrm{min}^{-1} \mathrm{~g}-{ }^{1}$. The levels of PO activities were significantly $(\mathrm{P} \leq 0.05)$ higher in all treatments compared to the control. PO activity in the leaves of tomato grown in T. harzianum fortified vermicompost was significantly higher than all other treatments at all intervals of time (Fig. 5).

\section{PPO Activity}

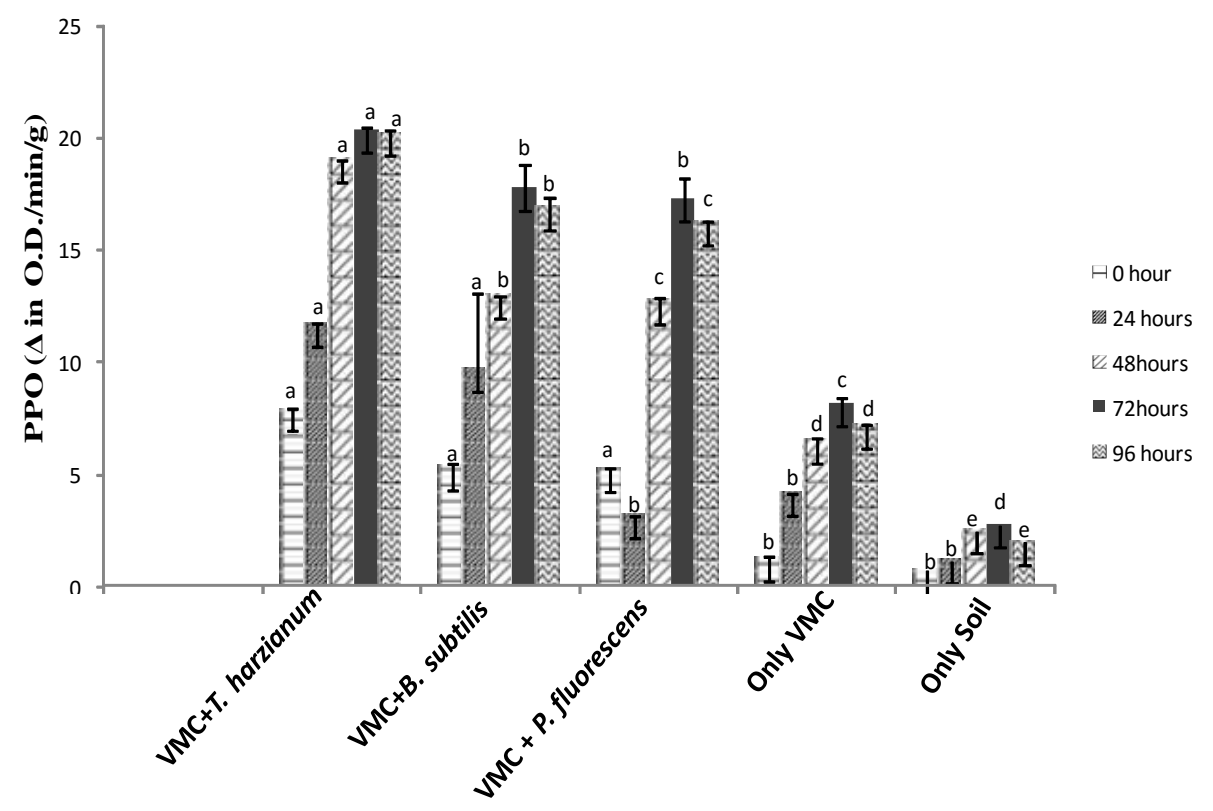

Fig.6 -Effect of microbial fortified vermicompost on PPO activity. Different letters indicate significant differences among treatments of results taken at the same time interval according to Duncan's multiple range test at $\mathrm{P} \leq 0.05$ )

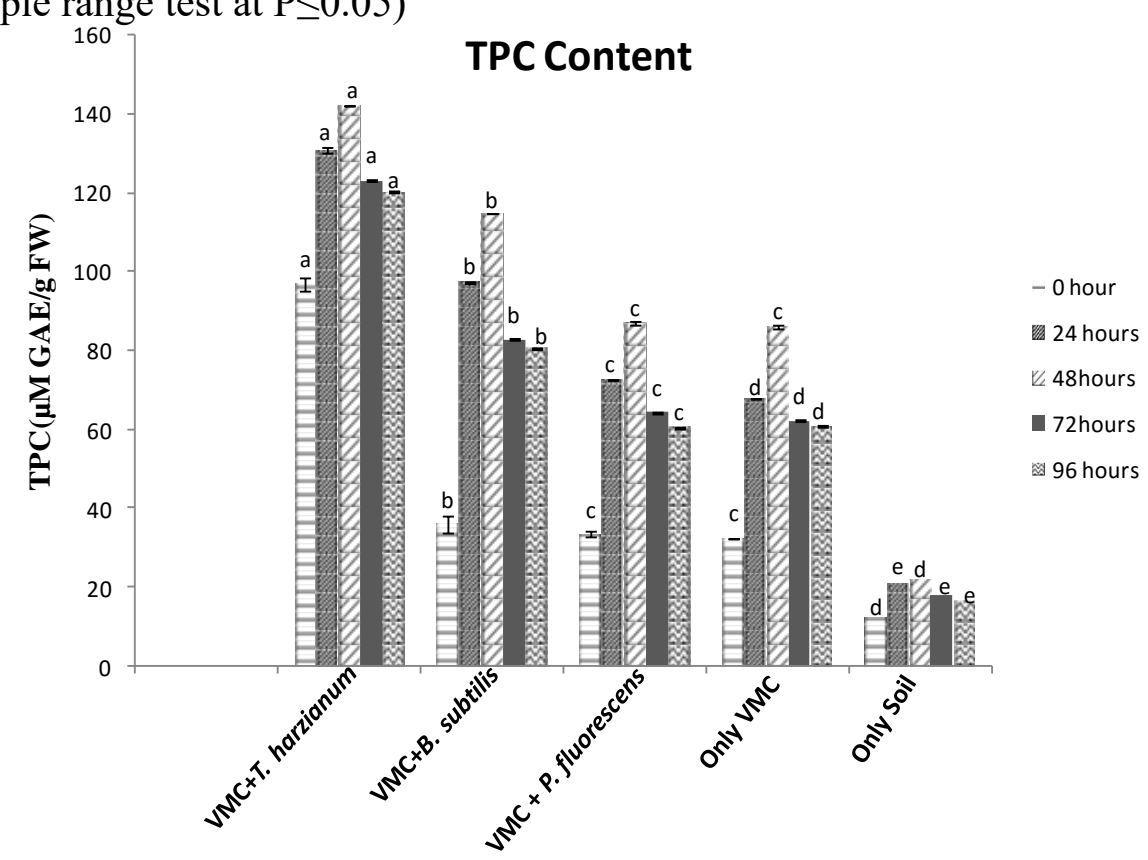

Fig.7 -Effect of microbial fortified vermicompost on TPC activity. Different letters indicate significant differences among treatments of results taken at same time interval according to Duncan's multiple range test at $\mathrm{P} \leq 0.05$. Results are expressed as means of three replicates and vertical bars indicate standard deviation of the means. 
The level of PPO activity in the leaf extracts were more in all treatments as compared to the control. PPO activity exhibited a significant increase after the pathogen inoculation up to $72 \mathrm{~h}$. After $72 \mathrm{~h}$, PPO activities started declining in all treatments. The highest PPO activity was recorded in case of $T$. harzianum fortified vermicompost (Fig. 6). However, no significant variations were recorded between the tomato plants grown in B. subtilis and T. harzianum fortified vermicompost.

Quantification of total free phenol content showed significant variations among the treatments. TPC varied from $142.05 \pm 0.61$ to $12.21 \pm 0.00 \mu \mathrm{M} \mathrm{GAEg}^{-1} \mathrm{FW}$. The highest amount of total phenol content was obtained in the case of $T$. harzianum fortified vermicompost at $48 \mathrm{~h}$ after inoculation with the pathogen (Fig. 7). The lowest level of TPC was observed in the control (plants grown only in the soil).

\section{SOD Activity}

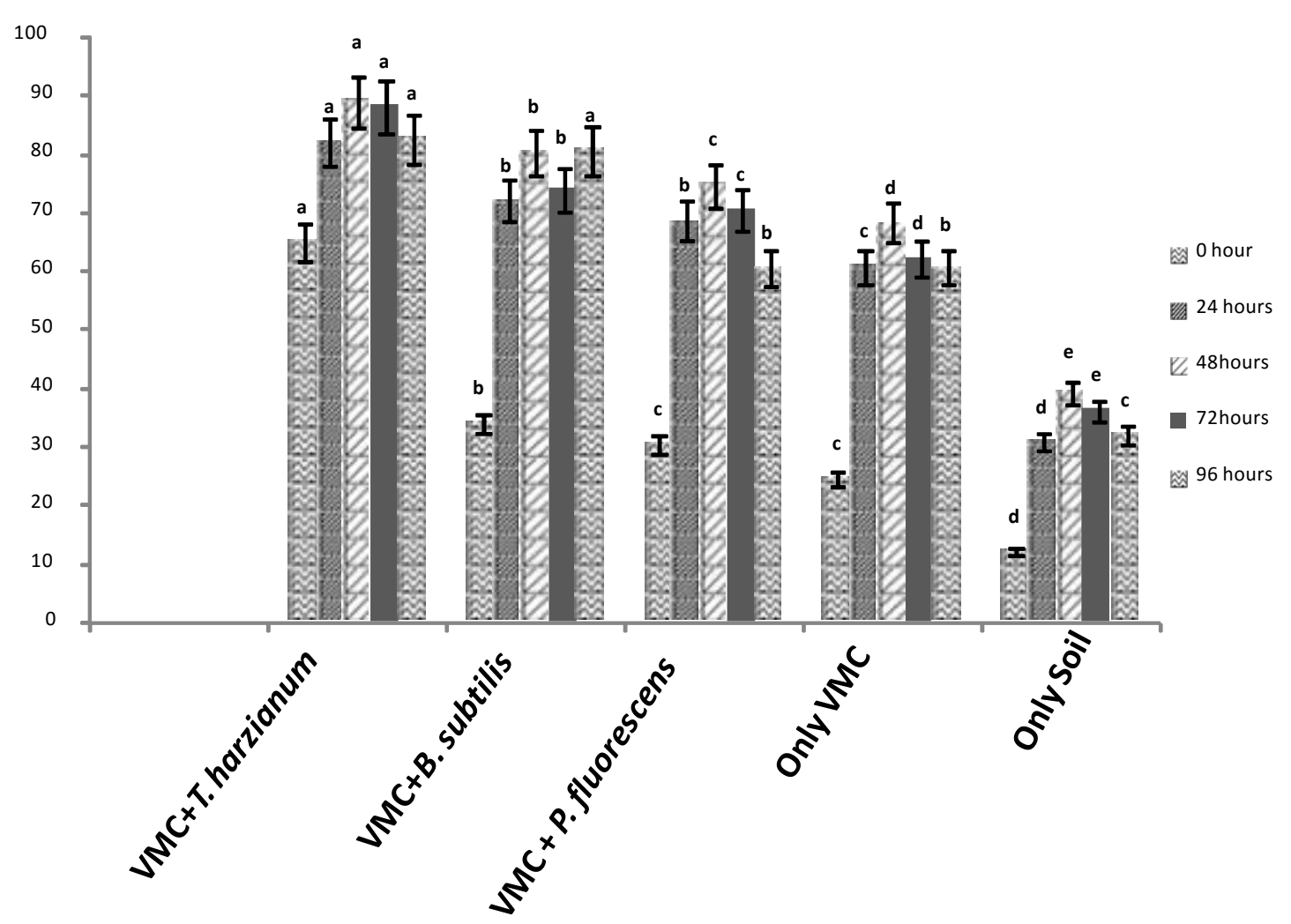

\section{Fig.8 - Effect of microbial fortified vermicompost on SOD activity}

To examine the effect of microbially fortified vermicompost on the levels of SOD activity, the enzymatic activity profile of SOD at various time points after pathogen inoculation was monitored. The magnitude of SOD induction in the leaves was recorded in the range of 12.21-89.2 $\mathrm{U} \mathrm{g}^{-1} \mathrm{FW}$. The dramatic induction of SOD activity in the leaves was observed during the first 3 days after treatment and the levels of SOD activity peaked at the $3^{\text {rd }}$ day and then declined gradually (Fig. 8).

The levels of $\mathrm{H}_{2} \mathrm{O}_{2}$ generation in the leaf extracts were higher in the plants grown in soil only as compared to the biofortified vermicompost treated plants. $\mathrm{H}_{2} \mathrm{O}_{2}$ generation exhibited a remarkable increase after the pathogen inoculation up to $72 \mathrm{~h}$. After $72 \mathrm{~h}$ the generation of $\mathrm{H}_{2} \mathrm{O}_{2}$ started declining (Fig. 9). Moreover, $\mathrm{H}_{2} \mathrm{O}_{2}$ generations in all treatments were significantly lower than that in the control and the lowest $\mathrm{H}_{2} \mathrm{O}_{2}$ generation was recorded in $T$. harzianum fortified vermicompost. 


\section{$\mathrm{H}_{2} \mathrm{O}_{2}$ Generation}

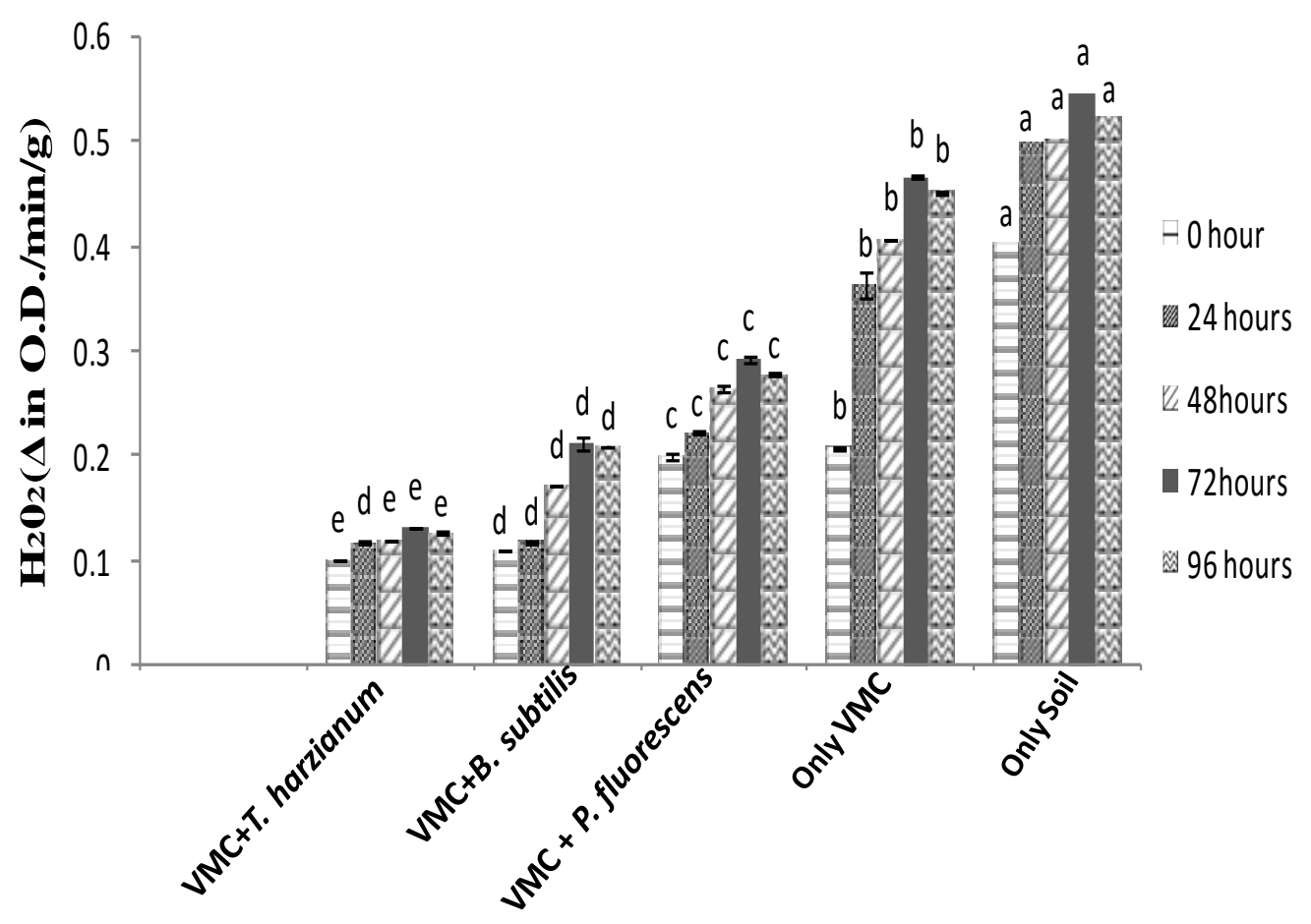

Fig.9 -Effect of microbial fortified vermicompost on $\mathrm{H}_{2} \mathrm{O}_{2}$ activity. Different letters indicate significant differences among treatments of results taken at same time interval according to Duncan's multiple range test at $\mathrm{P} \leq 0.05$.

\section{Disease Incidence}

Pot trials were carried out to examine the in vivo efficiency of microbial fortified vermicompost to antagonize $F$. oxysporum $\mathrm{f}$. sp. lycopersici under greenhouse conditions. Pot trial in greenhouse conditions showed that the use of either vermicompost alone or microbial fortified vermicompost protected the tomato plants from wilt incidence.

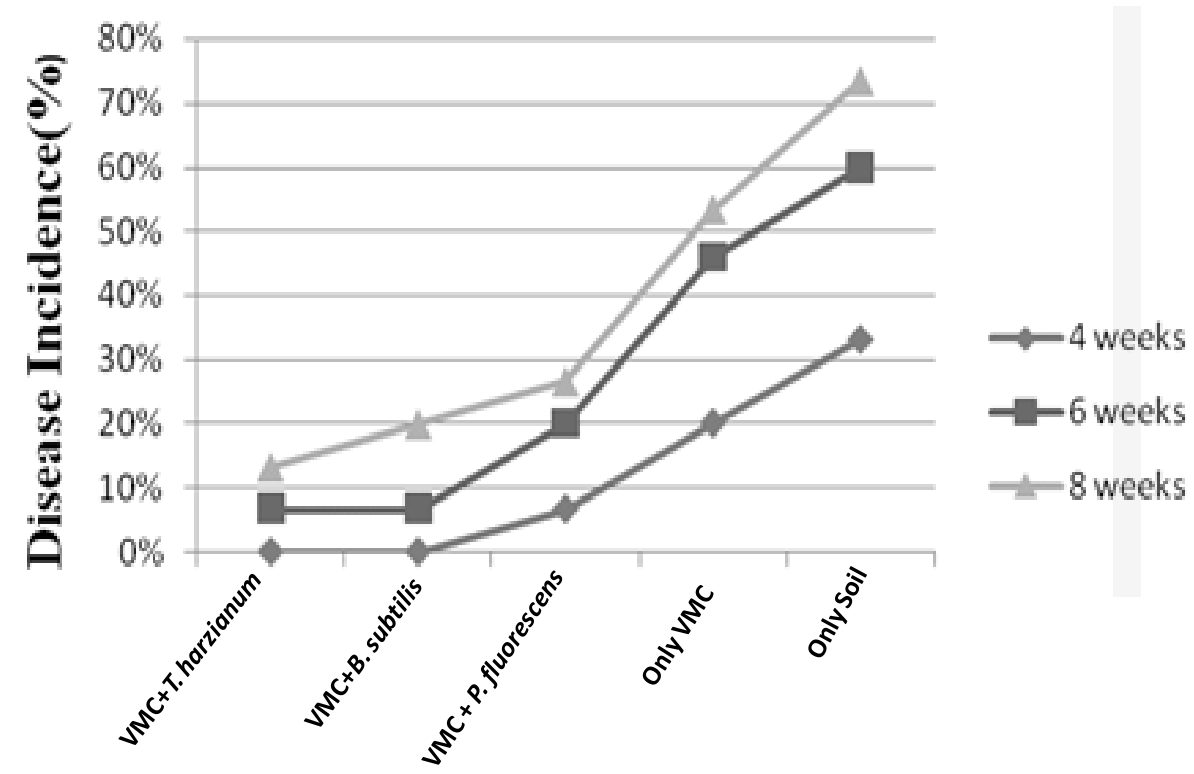

Fig.10 -Percentage of disease incidence after pathogen inoculation 
The results clearly demonstrate that the percentage of disease incidence was gradually and extremely increasing with time after infection. Tremendous increase of disease incidence was observed in plants grown in soil only and in unfortified vermicompost (Fig. 10).

\section{Discussion}

The management of persistent soil borne pathogens through chemical means is inefficient as it involves high cost and cause environmental hazard. An ecofriendly approach in crop protection to reduce the damage caused by fungal pathogens with several biocontrol agents were reported in many crops (Bharathi et al. 2004, Sarma et al. 2015, Mishra et al. 2015). Antagonistic effect of the fortified vermicompost with T. harzianum, B. subtilis and P. fluorescens and individual use of vermicompost was studied against $F$. oxysporum f. sp. lycopersici and results showed that biofortification not only reduced the incidence of tomato wilt but also promoted plant growth.

Dual culture assay showed effective antagonistic activity of BCAs against the test pathogen. Results presented in table1 indicate the varying degrees of inhibition of $F$. oxysporum f. sp. lycopersici by all the three biocontrol agents viz. T. harzianum, B. subtilis and P. fluorescens. The potentialities of the used strains could be attributed to their effect to secrete hydrolytic enzymes, different antibiotics or antifungal metabolites. Trichoderma spp. secrete various antimicrobial secondary metabolites (Keswani et al. 2014). Sarhan et al. (2001) pointed that the cell free culture filtrate of $B$. subtilis inhibited the mycelial growth, radial growth, spore germination and germtubes length of $F$. oxysporum.

Moreover, Alippi \& Monaco (1994) reported that B. subtilis can secrete several antifungal metabolites which have an inhibitory effect on fungal pathogens. All these observations represent an important approach for managing the root rot and wilt disease of tomato plants. This fact is also supported by Srivastava (2008) who reported that five Pseudomonas strains showed varied levels of antifungal activity and they were capable of inhibiting the growth of pathogenic microorganisms. According to his experiment, at $5000 \mu \mathrm{g} / \mathrm{mL}$, all the Pseudomonas strains (including Pf4-1) showed almost complete inhibition and maximum activity against Curvularia lunata and Fusarium spp.

In well managed compost / vermicompost there are millions of bacteria of a number of species. In addition, there are many types of protozoa, beneficial fungi and friendly nematodes that help to make up the soil food web. It is the range and diversity of microorganisms that make high quality compost (David \& Millner 2006). In this study, total microbial populations present in vermicompost were determined before microbial fortification of vermicompost and re- isolation was done 10 days after biofortification to check the microbial population dynamics. The common microbial genera observed in the vermicompost are typically in accordance with the ones mentioned by Nagavallemma et al. (2004).

Relatively, higher population of Bacillus spp. was observed in vermicompost before and after the biofortification of vermicompost as compared to the population of $T$. harzianum and $P$. fluorescens. This predominance of Bacillus spp. in vermicompost was also reported by Nagavallemma et al. (2004).

The results from this study indicated that the population of biocontrol agents in the vermicompost was significantly increased after fortification. The significant increase of the population density of BCAs, observed in the vermicompost was in agreement with the observations made by Kostov \& Lynch (1998) and Wu (1998) who reported that the pronounced effects of compost carriers in controlling wilt disease might be ascribed to the well-furnished medium for proliferation of biocontrol agents.

The introduction of biofortified vermicompost led to the significant results in terms of yield enhancement and reduction of disease incidence. The results presented in the figures1, 2 and 3 showed that there was a clear difference in growth promotion in tomato plants grown in microbial fortified vermicompost as well as in vermicompost alone. Highly significant variations were observed in root length, shoot length and dry weight among the treatments. 
Results of the current study are in accordance with the report of Priyanka et al. (2014) who reported that the application of vermicompost in addition to other bioinoculants in tomato promoted growth. In their study using different treatments, it was found that maximum growth in tomato plants was obtained where a combination of different treatments i.e. vermicompost, Bacillus pumilus, Trichoderma and a mycorrhizal fungus Glomus mosseae were used. Similar results were also reported by Bachman \& Metzger (2008) who stated positive effect on productivity enhancement and nematode management through vermicompost and bio-pesticides in brinjal. The findings of this study are also in agreement with many scientific reports which showed that either vermicompost or its combination with biocontrol agents have played a vital role in promoting growth. Bora \& Deka (2007) found that the biopesticide combination of vermicompost, $P$. fluorescens, carboxymethyl cellulose and mannitol showed best shelf life as it maintained highest population recovery. Gandhi \& Sundari (2012) found that the availability of macronutrients and micronutrients in different types of vermicompost enhanced plant growth (Solanum melongena L.).

The untreated plants i.e. plants grown in soil only (control) were characterized by higher disease incidence which increased significantly with increasing time of infection compared to healthy treated seedlings. Poor vegetative growth which led to almost zero yield was also observed in this group of plants (control). The results of this investigation confirm the findings of El-Khallal (2007) and Hanaa et al. (2011) who reported that the growth rate of shoot and root was markedly inhibited in tomato seedlings in response to Fusarium wilt disease. The reduction of shoot and root length in infected seedlings could be a morphological expression of hormonal imbalance. This hormonal imbalance in tomato seedling after Fusarium infection included the accumulation of ABA and reduction of IAA, GA3 and cytokinines (El-Khallal2007). In addition, the short root and shoot lengths in tomato seedlings infected with Fusarium oxysporum could be due to the production of some toxins by fungi and the accumulation of phenolic compounds produced from the cell wall degradation mainly lignin via depolymerization resulting from fungal elicitors (Steijl et al. 1999, Hanaa et al. 2011)

The evolution of wilt disease incidence in tomato plants infected with Fusarium oxysporum f. sp. lycopersici was recorded at different time interval. Data presented in the Figure 10 showed that the highest percentage of disease incidence was recorded in the control (plants grown in the soil), followed by plants grown in the vermicompost alone after 4, 6 and 8 weeks after infection. The obtained results clearly demonstrated that the percentage of disease incidence has gradually increased with increasing the duration of infection. Data presented by the Figure10 indicated that lower per cent of disease incidence was observed in the treatments of vermicompost biofortified with the selected biocontrol agents especially in T. harzianum fortified vermicompost. The results of this study are in agreement with the report of De Ceuster and Hoitink (1999) and Lubna (2008) who reported that composted pine bark mix fortified with $T$. hamatum has been very effective for control of Fusarium wilt of cyclamen and a disease caused by Rhizoctonia disease. The lower incidence of root rot disease of green bean in soil applied with compost and fortified with $T$. harzianum suggests that the growth substrate is conducive for rapid proliferation of biocontrol agents. Lubna (2008) also reported that disease severity in plants infested with $R$. solani was significantly reduced by the rice straw compost fortified with $T$. harzianum. The disease suppressive effect of fortified compost was also better than compost or $T$. harzianum treatment alone.

Induction of systemic resistance has been established as new mechanism by which plants defend themselves against the attack of various pathogens (Van Loon 1999). Application of microbial fortification of vermicompost with selected bioagents viz. T. harzianum, B. subtilis and $P$. fluorescens induced accumulation of higher levels of PAL, PO, PPO, free phenol and SOD in tomato plants than that of the control. Data presented from the figure 4, 5, 6, 7 and 8 shows that after 48 and $72 \mathrm{~h}$ of infection of PAL, PO, PPO, free phenolic content and SOD activities were higher in infected seedlings treated with biofortified vermicompost when compared with control or vermicompost alone. $T$. harzianum fortified vermicompost recorded higher antioxidant accumulation than that of $B$. subtilis and $P$. fluorescens fortified vermicompost generally from 48 to 
$72 \mathrm{~h}$ after pathogen infection. On the other hand, the use of vermicompost only has also induced a relatively higher systemic resistance as compared to the control which is in agreement with the previous report that vermicompost may affect different aspects of plant biochemical processes (Adewole \& Ilesanmi 2011, Priyanka et al.2014).

Singh et al. (2014) confirmed the induction of systemic resistance by Pseudomonas spp., Bacillus spp. and Trichoderma spp. against fungal pathogens. A study conducted by Hanaa et al. (2011) on the induction of antioxidant defensive enzymes in tomato seedlings indicated that infection with Fusarium oxysporum caused a significant increase in the activities of PO, SOD and CAT in tomato seedlings after 3 and 7 days of infection compared to non infected seedlings in control group

Conversely, higher production of $\mathrm{H}_{2} \mathrm{O}_{2}$ was observed in the set of control plants as compared to plants treated with the biofortified vermicompost or vermicompost alone. Higher accumulation of $\mathrm{H}_{2} \mathrm{O}_{2}$ in the set of control plants was negatively correlated with the accumulation of antioxidant enzymes which were observed in lower amount as compared to the plants treated with biofortified vermicompost. The lower accumulation of antioxidants and higher concentration of $\mathrm{H}_{2} \mathrm{O}_{2}$ is an indication of lack of /or poor systemic resistance after infection. This could be one of the reasons which made the control plants to be highly susceptible to the infection of $F$. oxysporum f. sp. lycopersici because higher incidence of disease was recorded in this group of plants. This observation is in agreement with Hanaa et al. (2011) who reported that in their experiment, the amount of antioxidants defensive enzymes observed in the untreated plants were not enough to protect from the pathogen infection. Similar results were also recorded by Luhova et al. (2006) who reported that PO activity after infection of tomato seedlings by $F$. oxysporum may participate in the removal of ROS and their accumulation in the plant tissues.

\section{Conclusion}

The evidence from this study showed that the use of vermicompost alone or after biofortification with agriculturally important microbes would be an eco-friendly approach for management of plant diseases which may contribute significantly to sustainable agriculture. In conclusion, application of vermicompost after biofortification with microorganisms like $T$. harzianum, $P$. fluorescens and B. subtilis increase growth and improve nutritional quality of tomato plants. Therefore, based on this study, biofortified vermicompost may be further exploited for large scale field trials thereby using them for sustainable disease management. Vermicomposting should also be understood as an effective way of keeping the surroundings clean and free of garbage by recycling organic waste materials into nutritionally rich products that would otherwise pose disposal problems for environment.

\section{Acknowledgement}

HBS is grateful to DBT $(\mathrm{P} / 07 / 555)$ for financial support. $\mathrm{KB}$ is grateful to $\mathrm{BHU}$ for providing financial support.

\section{References}

Adewole MB, Ilesanmi AO. 2011-Effects of soil amendments on the nutritional quality of okra(Abelmoschus esculentus L.). Journal of Soil Science and Plant Nutrition 11, 45-55.

Agrios GN. 2005 - Plant pathology, $5^{\text {th }}$ ed. Academic Press, Inc.: New York. P.922

Alippi A, Monaco C. 1994 - Antagonism in vitro deespeciesde Bacillus contra Sclerotium rolfsii Fusarium solani.RevistadelaFaculataddeAgronomiaLa Plata70, 91-95.

Azadeh BF, Sariah M, Wong MY. 2010 - Characterization of Burkholderia cepacia genome as a potential biocontrol agent of Ganoderma boninense in oil palm. African Journal of Biotechnology 9, 3542-3548.

Bachman GR, Metzger JD. 2008 - Growth of bedding plants in commercial potting substrate amended with vermicompost. Bioresources Technology 99, 3155-3161 
Bharathi R, Vivekananthan R, Harish S, Ramantha A, Samiyappan R. 2004 - Rhizobacteria-based bio-formulations forthe management of fruit rot infection in chilies. Crop Protection23, 835-843.

Bisen K, Keswani C, Mishra S, Saxena A, Rakshit A, Singh HB. 2015 - Unrealized potential of seed biopriming for versatile agriculture. In Nutrient Use Efficiency: from Basics to Advances (ed. A. Rakshit, H. B. Singh, A. Sen), Springer India, pp. 193-206.

Bisen K, Keswani C, Patel JS, Sarma BK, Singh HB. 2016 - Trichoderma spp.: Efficient Inducers of Systemic Resistance in Plants. In Microbial-mediated Induced Systemic Resistance in Plants (ed. D. K. Chaudhary, A. Varma) Springer Singapore, pp. 185-195.

Booth C. 1971- The genus Fusarium. The Eastern Press, CMI, London, England. 237 pp.

Bora LC, Deka SN. 2007 - Wilt disease suppression and yield enhancement in tomato (Lycopersicom esculentum ) by application of Pseudomonas fluorescens based pesticide (biof or Pf) in Assam. Indian Journal Agricultural Sciences 77, 490-494.

Cook RJ.1993- Making greater use of microbial inoculants in agriculture. Annual Review of Phytopathology124, 803-814.

Cotxarrera L, Trillas-Gayl MI, Steinberg C, Alabouvette C. 2002 - Use of sewage sludge compost and Trichoderma asperellum isolates to suppress Fusarium wilt of tomato. Soil Biology and Biochemistry 34, 467-476.

David I, Millner P.2006 - Additives Boost Pathogens in Compost Tea. Agricultural Research 54, 22.

De Ceuster TJ, Hoitink HAJ.1999 -Using compost to control plant diseases.Bio cycle Magazine. June, 61

El-Khallal SM. 2007- Induction of modulation of resistance in tomato plants against wilt diseases by bio agent fungi (Arbuscularmycorrhiza) and/ or hormonal elicitors (jasmonic acid and salicylic acid) 2 changes in the antioxidant enzymes, phenolic compounds and pathogen related proteins. Australian Journal of Basic and Applied sciences 1, 717-732.

Enespa, Dwivedi SK 2014 - Effectiveness of some antagonistic fungi and botanicals against Fusarium solani and Fusarium oxysporum f. sp. lycopersici infecting brinjal and tomato plants. Asian Journal Plant Pathology 8, 18-25.

Gandhi A, Sundari US. 2012- Effect of vermicompost prepared from aquatic weeds on growth and yield of eggplant (Solanum melongena L.). BiofertilizersBiopesticides3, 5.

Hanaa RMF, Abdou AZ, Salama DA, Ibrahim ARM, Sror HMA. 2011- Effect of neem and willow aqueous extracts on Fusarium wilt disease in tomato seedlings: Induction of antioxidant defensive enzymes. Annals of Agricultural Sciences 56, 1-7.

Heydari A, Misaghi IJ, Balestra GM. 2007 - Pre-emergence herbicides influence efficacy of fungicides in controlling cotton seedling damping off in the field. International Journal of Agricultural Research2, 1049-1053.

Huang A. 1991- Control of soil borne crop diseases by soil amendments.Plant Protection Bulletin (Taipei)33, 113-123.

Jain A, Singh S, Sarma BK, Singh HB. 2011 - Microbial consortium-mediated reprogramming of defence network in pea to enhance tolerance against Sclerotinia sclerotiorum. Journal of Applied Microbiology 112, 537-550.

Jasnic S, Vidić M, Bagi F, Đorđević V. 2005 - Pathogenicity of Fusarium species in soybean. ZbornikMaticesrpskezaprirodnenauke 109, 113-115.

Kannangowa T, Utkhede RS, Paul JW, Punja ZK. 2000 - Effect of mesophilic and thermophilic composts on suppression of Fusarium root and stem rot of greenhouse cucumber. Canadian Journal of Microbiology 46, 1021-1022.

Keswani C, Mishra S, Sarma BK, Singh, SP and Singh HB. 2014 - Unraveling the efficient applications of secondary metabolites of various Trichoderma spp. Applied microbiology and biotechnology 98, 533-544.

Keswani C. 2015 - Proteomics studies of thermotolerant strain of Trichoderma spp. Ph.D. Thesis, Banaras Hindu University, Varanasi. 
Khalil I, El-Mghrabia K. 2010 - Biological control of Fusarium dry rot and other potato tuber diseases using Pseudomonas fluorescens and Enterobacter cloacae. Biological Control 53, 280-284.

Kostov O, Lynch JM. 1998 - Composted spruce (Picaeaexcelsa Link) sawdust as a carrier for Bradyrhizobium, Rhizobium and Azospirillum in crop inoculation. World Journal of Microbiology and Biotechnology 14, 389-397.

LenucciMS, Cadinu D, Taurino M, Piro G, Dalessandro G. 2006 - Antioxidant composition in cherry and high-pigment tomato cultivars. Journal Agricultural Food Chemistry 54, 26062613.

Lubna SN 2008- Control of Root rot of green bean with composted rice straw fortified with $T$. harzianum.Phytopathology 75, 654-659.

Luhova L, Lebeda A, Kuteova E, Hedererova D, Pec P. 2006- Peroxidase, catalase, amine oxidase and acid phosphatase activities in Pisum sativum during infection with Fusarium oxysporum and $F$. Solani. Biologia Plantarum 4, 675-682.

Mishra S, Singh A, Keswani C, Saxena A, Sarma BK, Singh HB. 2015 - Harnessing plant-microbe interactions for enhanced protection against phytopathogens. In Plant Microbes Symbiosis: Applied Facets (ed. N. K. Arora), Springer India, pp. 111-125.

Mokhtar MM, El-Mougy NS. 2008- Bio-compost application for controlling soilborne plant pathogens- A review. Population 4, 154-162.

Navagallemma KP, Wani SP, Stephane L, Padmaja VV, Vinela C, Babu R M and Sahrawat KI 2004- Vermicomposting: Recycling wastes into valuable organic fertilizer. Global Theme on Agroecosystems Report no.8 Patacheru 502324. Andhra Pradesh, India: ICRISAT.20pp

Pitt D, Tilston EL, Groenhof AC, Szmidt RA. 1998 - Recycled organic materials (ROM) in the control of plant disease. Acta Horticulture 469, 391-403.

Patil S, Sriram S, Savitha MJ. 2011 - Evaluation of non-pathogenic Fusariumfor antagonistic activity against Fusarium wilts of tomato. Journal of Biological Control 25, 118-123.

Priyanka M, Pooja S, Tripathi NN.2014-Evaluation of plant extracts against Fusarium oxysporum f. sp. lycopersici, wilt pathogen of tomato. Research Journal of Microbiology 9, 129-134.

Sahni S, Sarma BK, Singh DP, Singh HB and Singh KP. 2008- Vermicompost enhances performance of plant growth-promoting rhizobacteria in Cicer arietinum rhizosphere against Sclerotium rolfsii. Crop Protection 27, 369-376.

Sarhan MM, Ezzat SM, Tohamy AA, ElEssawy AA, Mohamed FA. 2001 - Biocontrolof Fusarium tomato wilt diseases by Bacillus subtilis. Egypt Journal of Microbiology 36, 376-386.

Sarma BK, Yadav SK. Singh S. Singh HB. 2015 - Microbial consortium-mediated plant defense against phytopathogens: Readdressing for enhancing efficacy. Soil Biology and Biochemistry 87, 25-33.

Sarma BK, Singh P, Pandey SK ,Singh HB. 2010 - Vermicompost as modulator of plant growth and disease suppression. Dynamic Soil \& Dynamic Plant 4 (special issue 1), 58-66.

Scheuerell SJ, Sullivan DM, Mahaffee WF. 2005 - Suppression of seedling damping-off caused by Pythium ultimum, and Rhizoctonia solani in container media amended with a diverse range of Pacific Northwest compost sources. Phytopathology 95, 306-315.

Raja Sekar K, Karmegam N. 2010 - Earthworm casts as an alternate carrier material for biofertilizers: assessment of endurance and viability of Azotobacter chroococcum, Bacillus megaterium and Rhizobium leguminosarum. ScientiaHorticulturae124, 286-289.

Shanmugam, KR, Mallikarjuna K, Kesireddy N, Reddy KS. 2011- Neuroprotective effect of ginger on anti-oxidant enzymes in streptozotocin induced diabetic rats. Food and Chemical Toxicology, 49, 893-897

Singh R, Sharma RR, Kumar S, Gupta RK, Patil RT. 2008 - Vermicompost substitution influences growth, physiological disorders, fruit yield and quality of strawberry (Fragaria x ananassa Duch.). Bioresource Technology 99, 8507-8511. 
Singh A, Jain A, Sarma B K, Abhilash PC, Singh HB.2013-Solid waste management of temple floral offerings by vermicomposting using Eisenia feotida. Waste Management 33, 11131118.

Singh A, Sarma BK, Upadhyay RS, Singh HB 2013 - Compatible rhizosphere microbes mediated alleviation of biotic stress in chickpea through enhanced antioxidant and phenylpropanoid activities. Microbiological Research, 168(1), 33-40.

Singh BN, Singh A, Singh BR, Singh HB 2014- Trichoderma harzianum elicits induced resistance in sunflower challenged by Rhizoctonia solani. Journal of Applied Microbiology 116, 654666.

Song W, Zhou L, Yang C, Cao X, ZhangL, Liu X. 2004 - Tomato Fusarium wilt and its chemical control strategies in a hydroponic system. Crop Protection 23, 243-247.

Srivastava RS. 2008 - Antifungal Activity of Pseudomonas fluorescens against different plant pathogenic fungi.Internet Journal of Microbiology 7, 8-10.

Steij1 H, Niemann, GJ, Boon, JJ. 1999 - Changes in chemical composition related to fungal infection and induced resistance in carnation and radish investigated by pyrolysis mass spectrometry. Physiological and Molecular Plant Pathology 55, 297-311.

Subramanyam CV. 1970 - Hyphomycetes - An account of Indian species except Cercosporae. Indian Council of Agricultural Research, New Delhi.

Suneetha H. 2011- Effect of vermicompost on the antioxidant levels of Coleus aromaticus. International Journal of Science Innovations and Discoveries 1, 11-12.

Suresh P, Sriram S, Savitha MJ. 2011- Evaluation of non-pathogenic Fusarium for antagonistic activity against Fusarium wilts of tomato. Journal of Biological Control 25, 118-123.

Tiunov AV, Scheu S. 2004 - Carbon availability controls the growth of detritivores (Lumbricidae) and their effect on nitrogen mineralization. Oecologia 138, 83-90.

Van Loon LC.1999- Induction of defense resistance in plants and the role of pathogenesis related proteins. European Journal of Plant Pathology103: 532-544.

Verma M, Brar S, Tyagi R, Surampalli R, Valero J. 2007 - Antagonistic fungi, Trichoderma spp. panoply of biological control. Journal of Biochemical Engineering37, 1-20.

Whipps JM. 1997 - Developments in the biological control of soilborne plant pathogens. Advances in Botanical Research. Academic Press, UK, pp. 1-134.

Wu C, Hsiang T, Yang L, Liu LX. 1998 - Efficacy of Typhulaphacorrhiza as a biocontrol agent of gray snow mold of creeping bent grass. Canadian Journal of Botany 76, 1276-1281. 